\title{
Analysis for prevalence and physical linkages amongst integrons, ISEcp1, ISCR1, Tn21 and Tn7 encountered in Escherichia coli strains from hospitalized and non-hospitalized patients in Kenya during a 19-year period (1992-2011)
}

\author{
John Kiiru ${ }^{1,2,3^{*}}$, Patrick Butaye ${ }^{3,4}$, Bruno M Goddeeris ${ }^{2,5}$ and Samuel Kariuki ${ }^{1}$
}

\begin{abstract}
Background: We determined the prevalence and evidence for physical linkage amongst integrons, insertion sequences, Tn21 and Tn7 transposons in a collection of 1327 E. coli obtained over a 19-year period from patients in Kenya.

Results: The prevalence of class 1 integrons was 35\%, class 2 integrons were detected in 3 isolates but no isolate contained a class 3 integron. Integron lacking the $3^{\prime}$-CS or those linked to sul3 gene or IS26 or those containing the ISCR1 were only detected in multidrug resistant (MDR) strains. The dfrAs were the most common cassettes and their prevalence was: - $d f r A 1(28 \%), d f r A 12(20 \%), d f A 17(9 \%), d f r A 7(9 \%)$, and $d f r A 16(5 \%)$. The aadA were the second most abundant cassettes and their prevalence was: - aadA1(25\%), aadA2(21\%), and aadA5(14\%). Other cassettes occurred in lower prevalence of below 5\%. Prevalence of Tn21, ISECP1, ISCR1 and IS26 was 22\%, 10\%, 15\%, and 7\% respectively. Majority of Tn21 containing integrons carried a complete set of transposition genes while class 2 integrons were borne on Tn7 transposon. The gnrA genes were detected in 34(3\%) isolates while 19(1\%) carried qnrB. All gnr genes were in MDR strains carrying integrons containing the ISCR1. Close to 88\% of blaTEM-52 were linked to IS 26 while $\geq 80 \%$ of bla $a_{C T X-M s}$ and bla $a_{C M Y s}$ were linked to ISECP1. Only a few studies have identified a bla $a_{C T X-M-9}$ containing an ISECP1 element as reported in this study. Multiple genetic elements, especially those borne on incll, incFIl, and incL/M plasmids, and their associated resistance genes were transferrable en bloc to E. coli strain $J 53$ in mating experiments.

Conclusions: This is the first detailed study on the prevalence of selected elements implicated in evolution of resistance determinants in a large collection of clinical E. coli in Africa. Proliferation of such strains carrying multiple resistance elements is likely to compromise the use of affordable and available treatment options for majority of poor patients in Africa. There is therefore a need to monitor the spread of these highly resistant strains in developing countries through proper infection control and appropriate use of antimicrobials.
\end{abstract}

\footnotetext{
* Correspondence: jndemi@yahoo.com

${ }^{1}$ Centre for Microbiology Research, Kenya Medical Research Institute, PO Box 19464-00202, Nairobi, Kenya

${ }^{2}$ Department of Biosystems, Faculty of Bioscience Engineering, Katholieke Universiteit Leuven, Kasteelpark Arenberg 30, B-3001, Heverlee, Belgium Full list of author information is available at the end of the article
} 


\section{Background}

Recent studies conducted in Kenya show that a significant proportion of $E$. coli strains from clinical specimens exhibit a strong multi-drug resistance (MDR) phenotype $[1,2]$. Fortunately, $\beta$-lactams, fluoroquinolones and aminoglycosides remain effective against a significant proportion of clinical E. coli strains in Kenya. However, recent studies have reported carriage of plasmid-borne $a a c\left(6^{\prime}\right)$ $l b$ - $c r$ and $q n r$ genes among $\beta$-lactamase producers $[1,2]$. The qnr genes confer resistance to quinolones, while aac $\left(6^{\prime}\right)-l b-c r$ confers reduced susceptibility to fluoroquinolones and aminoglycosides. Therefore, carbapenems remain some of the few alternative antimicrobials that are effective against strains harboring a combination of multiple $\beta$-lactamase (bla) genes and genes conferring broad-spectrum resistance to fluoroquinolones and amino- glycosides. Carbapenems may however not be readily available or affordable for many patients in Sub-Saharan Africa [3].

In a recent study, we reported carriage of integrons, IS elements, $\operatorname{Tn} 21$ and $\operatorname{Tn} 7$ in a collection of $27 \mathrm{E}$. coli strains obtained from hospitalised patients [1]. These strains also harbored conjugatively transferrable plasmids conferring resistance to $\beta$-lactams, fluoroquinolones, aminoglycosides and co-trimoxazole among other antimicrobials suggesting that genes encoding resistance to these antimicrobials are physically linked to each other. Carriage of physically linked elements, each containing a set of resistance genes, may increases the chances of en bloc horizontal transfer of multiple resistance determinants to susceptible strains. Carriage of multiple resistance elements may in turn confer unique advantages to the

Table 1 Susceptibility profiles of isolates and their distribution in various specimen-types obtained from different categories of patients

\begin{tabular}{|c|c|c|c|c|c|c|c|}
\hline & \multirow[b]{2}{*}{$\begin{array}{l}\text { Number of resistant } \\
\text { strains } n=1327\end{array}$} & \multirow[b]{2}{*}{$\begin{array}{l}\% \text { of resistant } \\
\text { strains }\end{array}$} & \multicolumn{3}{|c|}{$\begin{array}{l}\text { Distribution [Number,\%] of resistant } \\
\text { strains in different specimen types }\end{array}$} & \multicolumn{2}{|c|}{$\begin{array}{l}\text { Distribution [Number,\%] of resistant } \\
\text { strains according to patient category }\end{array}$} \\
\hline & & & Stool $n=505$ & Urine $n=451$ & Blood $n=371$ & Inpatient $n=654$ & Outpatient $n=673$ \\
\hline AMOX & 756 & 57 & $225(30)$ & $355(57)$ & $176(23)$ & $439(58)$ & $318(42)$ \\
\hline AMP & 809 & 61 & 253 (31) & $373(46)$ & $184(23)$ & $518(64)$ & $292(36)$ \\
\hline AMC & 478 & 36 & $143(30)$ & $249(52)$ & $86(18)$ & $329(69)$ & $148(31)$ \\
\hline AMS & 544 & 41 & $153(28)$ & $288(53)$ & $103(19)$ & $343(63)$ & $201(37)$ \\
\hline TZP & 279 & 21 & $85(30)$ & $141(51)$ & 53 (19) & $226(81)$ & 53 (19) \\
\hline $\mathrm{AZT}$ & 385 & 29 & $121(31)$ & $191(50)$ & $73(19)$ & $258(67)$ & $127(33)$ \\
\hline CEF & 411 & 31 & $121(29)$ & $256(62)$ & $34(8)$ & $234(57)$ & $177(43)$ \\
\hline CRO & 358 & 27 & $97(27)$ & $184(51)$ & $78(22)$ & $266(74)$ & $93(26)$ \\
\hline CTX & 372 & 28 & $102(27)$ & $197(53)$ & 73 (19) & $290(78)$ & $82(22)$ \\
\hline CAZ & 279 & 21 & $83(30)$ & $142(51)$ & $54(19)$ & $201(72)$ & $78(28)$ \\
\hline FEP & 119 & 9 & $31(26)$ & $76(64)$ & $12(10)$ & $99(83)$ & $20(17)$ \\
\hline FOX & 106 & 8 & 19 (18) & 79 (74) & $8(6)$ & 87 (82) & 19 (18) \\
\hline NA & 239 & 18 & $86(36)$ & $132(55)$ & $21(9)$ & $163(68)$ & $77(32)$ \\
\hline CIP & 106 & 8 & 19 (18) & 79 (75) & $8(8)$ & $65(61)$ & 41 (39) \\
\hline STRP & 491 & 37 & $145(30)$ & $271(55)$ & 75 (15) & $290(59)$ & $201(41)$ \\
\hline $\mathrm{K}$ & 305 & 23 & $85(28)$ & $167(55)$ & $53(17)$ & $195(64)$ & $110(36)$ \\
\hline $\mathrm{CN}$ & 239 & 18 & $71(30)$ & $131(54)$ & 37 (16) & $170(71)$ & 69 (29) \\
\hline NEO & 212 & 16 & 71 (34) & $120(56)$ & $21(10)$ & $174(82)$ & 38 (18) \\
\hline $\mathbf{F}$ & 385 & 29 & $89(23)$ & $254(66)$ & $42(11)$ & $277(72)$ & $108(28)$ \\
\hline$C$ & 478 & 36 & 167 (35) & $233(49)$ & 78 (16) & $320(67)$ & $158(33)$ \\
\hline SUL & 637 & 48 & $189(30)$ & $356(56)$ & 92 (14) & $440(69)$ & 197 (31) \\
\hline TET & 703 & 53 & $218(31)$ & $353(50)$ & 132 (19) & $478(68)$ & $225(32)$ \\
\hline TRIM & 557 & 42 & $167(30)$ & $290(52)$ & 100 (18) & 379 (68) & $178(32)$ \\
\hline
\end{tabular}

The distribution of resistant strains in different specimen-types obtained from inpatients and outpatients. The percentages are calculated based on the total number of strains resistant to a given antimicrobial in different specimen types and category of patients. AMOX: amoxicillin, AMP: ampicillin, AMC: amoxicillinclavulanic acid, AMS: ampicillin-sulbactam, TZP: piperacillin-tazobactam, AZT: Aztreonam, CEF: cefuroxime, CRO: ceftriaxone, CTX: cefotaxime, CAZ: ceftazidime, FEP: cefepime, FOX: cefoxitin, NA: nalidixic acid, CIP: ciprofloxacin, STRP: streptomycin, K: kanamycin, CN: gentamicin, NEO: neomycin, F: nitrofurantoin, C: chloramphenicol, SUL: sulfamethoxazole, TET: Tetracylines, TRIM: Trimethoprim. 
host and enable them survive a strong antimicrobial selection pressure especially in hospital settings [4].

Studies to determine the prevalence of resistance elements in a large collection of strains from Sub-Saharan Africa are still lacking. Furthermore, little is known on whether the genetic elements encountered among $E$. coli strains in this region are physically linked to each other. In this study, we determined the prevalence of integrons, ISEcp1, ISCR1, IS26 as well as transposons Tn21 and Tn7 in a collection of 1327 E. coli strains obtained from inpatient and outpatient populations seeking treatment in Kenyan hospitals during a 19-year period (19922011). We also determined genetic content of integrons and determined plasmid incompatibility groupings among strains exhibiting unique resistance phenotypes. Physical linkages among these elements and to bla genes were investigated using PCR methods. Similar analysis were done to determine if the $a a c\left(6^{\prime}\right)-l b-c r$ and $q n r$ genes are physically linked to these elements.

\section{Results}

Antimicrobial susceptibility profiles

At least $25 \%$ of the 1327 isolates were resistant to expanded-spectrum $\beta$-lactams such as aztreonam (AZT), ceftriaxone (CRO), cefotaxime (CTX) and amoxicillinclavulanic acid (AMC) combunation and to none- $\beta$ lactams such as streptomycin (S), nitrofurantoin (F), chloramphenicol (C), sulfamethoxazole (SUL), tetracyclines (TET) and trimethoprim (TRIM), Table 1. Resistance to a combination of two $\beta$-lactamase inhibitors, AMC and pipperacillin-tazobactam (TZP), was recorded in $22 \%$ of the isolates while $20 \%$ and $9 \%$ exhibited an ESBL- or an AmpC-like phenotype respectively, Table 2. A total of 106 strains were resistant to combinations of SUL, TRIM, ciprofloxacin (CIP), cefepime (FEP), gentamicin $(\mathrm{CN})$, cefoxitin $(\mathrm{FOX})$ and TZP. These isolates were therefore identified as strains with the highest potential to limit therapeutic option in clinical settings. Imipenem (IMI), cefepime FEP and CIP were effective against $\geq 90 \%$ of isolates. Strains from urine were more likely to exhibit an MDR phenotype compared to those from stool (p:0.0001, CI:27.2 to 84.8, OR:42) or blood (p:0.0001, CI:12.8 to 30.8, OR:19.9). Similarly, MDR phenotypes were more common among strains from hospitalized patients than those from non-hospitalized patients ( $\mathrm{p}: 0.0001$, CI: 4.0 to 6.6 , OR:5.1).

\section{Prevalence of integrons and integron cassettes}

Class 1 integrons were detected in $35 \%$ of all isolates, 3 isolates carried class 2 integrons but none tested positive for class 3 integrons. The $d f r A$ sub-types conferring resistance to TRIM and the aadA-type cassettes conferring resistance to aminoglycosides were the most common cassettes in class 1 and 2 integrons, Table 3 . The prevalence of cassettes encoding resistance to trimethoprim was: - dfrA1 (28\%), dfrA12 (20\%), dfA17 (9\%), dfrA7 (9\%), and $d$ frA16 (5\%), while that of aadA cassettes conferring resistance to aminoglycosides was as follows: - aadA1 (25\%), aadA2 (21\%), and aadA5 (14\%). Despite a relatively high prevalence of resistance to $\beta$-lactams, only bla $a_{O X A-1}$ was identified as an integron cassette. While $\operatorname{aad} A$ and $d f r A$ types were detected in strains exhibiting resistance to between 2 and 8 classes of antimicrobials, $d$ frB, aadA5, bla $a_{O X A-1}, a a c\left(6^{\prime}\right)-l b-c r$, and $a r r 2$ were detected only in strains resistant to at least 6 different classes of antimicrobials. Majority (78\%) of $d f r A 17$ were detected in strains resistant to multiple generations of $\beta$-lactams.

The $c m l A 1$ and aadA1/dfrA1 cassette arrays were only detected in integrons containing a 3'-CS. In contrast, at least $64 \%$ of aac $\left(6^{\prime}\right)-l b-c r, d f r A 12 / a a d A 1 / b l a_{\text {oxa1 }}$, orf5/ dfrB/orfA, and $\operatorname{aac}\left(6^{\prime}\right) I b / b l a_{\text {oxa-1 }} /$ catB3/arr2 cassette arrays were detected in integrons lacking typical 3'-

Table 2 Distribution of isolates exhibiting combined resistance to selected antimicrobials

\begin{tabular}{|c|c|c|c|c|c|c|}
\hline & $\begin{array}{l}\text { Total isolates exhibiting } \\
\text { a given phenotype }\end{array}$ & Stool & Urine & Blood & Inpatient & Outpatient \\
\hline $\begin{array}{l}\text { SUL, TRIM, CIP + CN + FEP + FOX + TZP } \\
\text { and aminoglycosides }\end{array}$ & 106 & $30(28)$ & $57(54)$ & $19(18)$ & $87(82)$ & $19(18)$ \\
\hline $\mathrm{F}+\mathrm{SUL}+\mathrm{TRIM}+\mathrm{TET}+\mathrm{C}^{\mathrm{b}}$ & 451 & $121(27)$ & $233(52)$ & $97(22)$ & $322(71)$ & $129(29)$ \\
\hline $\mathrm{AMC}+\mathrm{AMS}^{\mathrm{C}}$ & 411 & $125(30)$ & $218(53)$ & $68(17)$ & $255(62)$ & $156(38)$ \\
\hline$A M S+A M C+T Z P^{C}$ & 291 & $87(30)$ & $172(59)$ & $32(11)$ & $194(67)$ & $97(33)$ \\
\hline ESBL strains & 272 & $95(35)$ & $133(49)$ & $44(16)$ & $188(69)$ & $84(31)$ \\
\hline Isolates with an AmpC-like phenotype & 122 & $38(31)$ & $72(59)$ & $12(10)$ & $93(76)$ & $29(24)$ \\
\hline
\end{tabular}

Distribution of strains resistant to different combinations of antimicrobials among different specimen-types obtained from inpatient and outpatients. CIP: ciprofloxacin, CN: gentamicin, FEP: cefepime, FOX: cefoxitin, TET: tetracyclines, TZP: piperacillin-tazobactam, F: nitrofurantoin, SUL: sulfamethoxazole, TRIM: Trimethoprim, C: chloramphenicol, AMC: amoxicillin-clavulanic, AMS: ampicillin-sulbactam.

ESBL strains are susceptible to AMC and cephamycins but resistant to various combinations of cephalosporins while isolates with an AmpC-like phenotype are resistant to cephalosporins and cephamycins.

a: Isolates were resistant to at least one aminoglycoside.

b: These antimicrobials are relatively cheap and are readily available in developing countries.

c: Combinations of $\beta$-lactamase inhibitors that may be used to treat infections caused by strains that are resistant to $\beta$-lactams. 
Resistance to selected antimicrobials in randomly selected strains carrying a given integron array
Classes of antimicrobials to which the host strain was resistant
Distribution [number, (\%)] of cassette arrays of cassette arrays in different types of integrons

Integrons Integrons Prevalence among isolates with integrons $(n=464)$

\section{Class 1 integrons arrays}

dfrA1

dfrA1/aadA1

dfra17/aadA5

dfra7

$\operatorname{aadA1}$

dfrA12/aadB

dfrA16/aadA2

aadA2/dfrA12

dfrA12/aadA2

aadA5

blaoxa-1/aadA1

blaoxa-1/aadA2

drA12/orfF/aadA2

$\operatorname{aac}\left(6^{\prime}\right) / b / c a t B 1 / d f r A 1$

$\operatorname{aadA1/dfrA1}$

$\operatorname{aac}\left(6^{\prime}\right) / b / b / a_{\text {oxa-1 }} /$ catB3/arr2

aadA2/orff/dfrA12

$\mathrm{cm} / \mathrm{A} 1$

orf5/dfrB/orfA

dfrA12/aadA1/bla oxa1

$\operatorname{aac}\left(6^{\prime}\right)-1 b-c r$

Class 2 Integron arrays
TRIM, SUL, TET,

TRIM, STP, AMP, C, CTX, CAZ, CIP, NA

TRIM, STP, C, AMP, C, CTX, CAZ, CIP, NA, FOX, AMC

TRIM, SMX, TET

TRIM, STRP, CN, K, TOB, AMP, C, CTX, AMC

TRIM, STP, K, TOB, AMP, C, CTX, AMC

STP, TRIM, TET, C, SUL, AMP, CTX, AMC,

TRIM, STP, TET, C, SUL

STP, AMP, SUL, TET

STP, AMP, C, TET, CTX, CAZ, CIP, NA, FOX, AMC

STP, AMP, C, TET, CTX, CAZ, CIP, NA, FOX, AMC

TRIM, STP, C, TET, CTX, NA, AMC

CN, TOB, C, TRIM, K, AMP, C, TET, CTX, CAZ, CIP, NA

STP, TRIM AMP, C, TET, CTX, NA, AMC

CN,TOB, K, C, RIF, AMP, C, TET, CTX, CAZ, CIP, NA, FOX, AMC

\section{STP, AMP, TRIM, SUL, TET}

C, TET, CTX, NA, AMP

TRIM, CN,TOB, C, AMP, C, TET, CTX, CAZ, CIP, NA, AMC

TRIM, STP, CN,TOB, AMP, C, TET, CTX, CAZ, CIP, NA,

CN, K, TOB, C, AMP, C, TET, CTX, CAZ, CIP, NA, AMC

$\begin{array}{cc}2 \text { to } 4 & 60(13) \\ 5 \text { to } 8 & 51(11) \\ 5 \text { to } 8 & 42(9) \\ 2 \text { to } 8 & 42(9) \\ 2 \text { to } 6 & 23(5) \\ 4 \text { to } 8 & 23(5) \\ 6 \text { to } 8 & 23(5) \\ 3 \text { to } 6 & 28(6) \\ 3 \text { to } 8 & 23(5) \\ 7 \text { to } 8 & 23(5) \\ 8 & 23(5) \\ 7 \text { to } 8 & 9(2) \\ 6 \text { to } 8 & 9(2) \\ 5 \text { to } 8 & 9(2) \\ 3 \text { to } 8 & 9(2) \\ 8 & 9(2) \\ 7 \text { to } 8 & 5(1) \\ 3 \text { to } 8 & 3(<1) \\ 6 & 3(<1) \\ 8 & 5(1) \\ 8 & 42(9)\end{array}$

$\begin{array}{cc}53(88) & 7(12) \\ 42(82) & 9(18) \\ 34(81) & 8(19) \\ 35(83) & 7(17) \\ 19(83) & 4(17) \\ 19(83) & 4(17) \\ 22(96) & 1(4) \\ 26(93) & 2(7) \\ 22(96) & 1(4) \\ 22(96) & 1(4) \\ 22(94) & 1(4) \\ 8(88) & 1(12) \\ 8(88) & 1(12) \\ 7(78) & 2(22) \\ 9(100) & 0 \\ 2(22) & 7(78) \\ 4(80) & 1(20) \\ 3(100) & 0 \\ 0 & 3(100) \\ 0 & 5(100) \\ 15(36) & 27(64) \\ & \end{array}$

drfA1/sat2/aadA1

TRIM, STRP, CN, K, TOB, AMP, C, CTX, AMC

6 to 8

$3(<1)$

NA

NA

The integron cassette arrays are indicated in the order they appear within class 1 and 2 integron variable cassette region (in the $5^{\prime}-3^{\prime}$ orientation).

The resistance phenotype associated with a given array is indicated in bold.

a: Different antimicrobials tested in this study were conveniently grouped into 8 groups:- $\beta$-lactams and $\beta$-lactamase inhibitors, aminoglycosides, (fluoro)quinolones, nitrofurantoin, chloramphenicol, sulphonamides, trimethoprim, and tetracyclines.

b: These integrons carried a sul3 gene at the $3^{\prime}$-end or lacked this gene or 3 '-CS comprising the gacEL1-sul1 genes. 
conserved sequences (3'-CS) that contains qacED1 (a truncated gene encoding resistance to quaternary ammonium compounds, and sul1 encoding resistance to sulfonamides). All the three class 2 integrons contained an identical cassette array comprising dfrA1-sat2-aadA1.

\section{Prevalence of $\mathrm{Tn} 21, \mathrm{Tn} 7$ and IS elements}

The prevalence of Tn21 was $22 \%$ while Tn7 was detected in 3 isolates that also carried class 2 integrons. Prevalence of ISEcp 1 , ISCR 1 and IS 26 was $10 \%, 15 \%$, and $7 \%$ respectively. A high proportion $(\geq 60 \%)$ of isolates containing the IS elements and integrons were MDR (resistant to at least 3 different classes of antimicrobials), Table 4. Isolates carrying multiple elements were more likely to exhibit an MDR phenotype than those lacking such elements (p:0.0001, CI:549.5 to 2419.6, OR:1153) and isolates from urine were more likely to harbor multiple elements compared to those from blood (p:0.0001, CI:3.1 to 5.5, OR:4.1) or those from stool (p:0.0008, CI:1.2 to 2.0, OR:1.6). Although integrons, IS elements and $\operatorname{Tn} 21$ were detected in isolates from all specimen-types, a high proportion (69\%) of these elements were detected among strains from urine of hospitalized patients.

\section{Physical linkage amongst genetic elements}

Figure 1 illustrates the strategy used for interrogation for physical linkages amongst genetic elements while Figure 2 illustrates some of the genetic associations identified in this study. Majority (69\%) of integrons containing 3'-CS were physically linked to the $\operatorname{Tn} 21$ transposon while $75 \%$ of those containing a sul3 gene at the 3'-terminal were linked to IS26. This element was also linked to $80 \%$ of integrons lacking the 3'-CS, Table 5. Forty (40) isolates contained class 1 integrons linked to a single IS26 upstream the 5'-CS while in 12 isolates the integrons was flanked by two IS26 elements. All ISCR1 were detected only in MDR strains and were flanked by a pair of class 1 integron 3'-CS. Close to $94 \%$ of $\operatorname{Tn} 21$ that were linked to an integron contained a complete set of transposition genes $(\operatorname{tnp} A, \operatorname{tnpR}$ and $\operatorname{tnpM)}$ while $89 \%$ of $\operatorname{Tn} 21$ with an incomplete set of these genes did not contain an integron, Table 6. All the three class 2 integrons were physically linked to $\operatorname{Tn} 7$.

\section{Physical linkages between resistance genes and genetic elements}

Figure 2 illustrates selected examples of physical linkages between bla genes and different genetic elements. Over $40 \%$ of isolates carrying $b l a_{T E M-52}, b l a_{S H V-5}$ or $b l a_{C T X-M-14}$ were physically linked to the IS 26 , Table 7. The ISEcp 1 was the most common IS element associated with bla $a_{C T X-M-14}, b l a_{C T X-M}-15$ and $b l a_{C M Y-2}$. One isolate contained a $b l a_{\mathrm{CTX}-M-9}$ linked to this element. In all cases, the ISEcp 1 was detected upstream the bla gene, Figure 2 .

Thirty seven (88\%) of the $42 a a c\left(6^{\prime}\right)-l b-c r$ were borne on integrons containing the ISCR1 while $55 \%$ were borne on integrons linked to the IS26. Twenty four (71\%) of the 34 isolates carrying a qnrA gene were resistant to nalidixic acid but not to ciprofloxacin while the other 10 isolates carrying this gene and 19 carrying the $q n r B$ subtype were resistant to both antimicrobials, Table 8. None of the isolates tested positive for $q n r S$. Majority (87\%) of qnr genes were physically linked to either integron-associated ISCR1 or the IS26. All Isolates carrying $a a c\left(6^{\prime}\right)-l b-c r$ or the $q n r$ genes contained multiple genetic elements and were all MDR.

Table 4 Carriage of resistance genetic elements among 1327 E. coli exhibiting resistance to different classes of antimicrobials

\begin{tabular}{|c|c|c|c|c|c|c|}
\hline \multirow[b]{2}{*}{ Combinations of genetic elements } & \multirow[b]{2}{*}{$\begin{array}{l}\text { Isolates positive for } \\
\text { genetic elements }\end{array}$} & \multirow[b]{2}{*}{$\begin{array}{c}\% \text { among } \\
1327 \text { isolates }\end{array}$} & \multicolumn{4}{|c|}{ Classes of antimicrobials to which host strains were resistant ${ }^{\mathrm{a}}$} \\
\hline & & & 0 & $1 \leq 2$ & $3 \leq 5$ & $6-8$ \\
\hline Integrons & 464 & 35 & 0 & $37(8)$ & $65(14)$ & $362(78)$ \\
\hline ISCR1 & 199 & 15 & 0 & 0 & $18(9)$ & $181(91)$ \\
\hline$|S E c p|$ & 128 & 10 & 0 & 0 & $35(27)$ & $93(73)$ \\
\hline IS26 & 86 & 7 & 0 & 0 & $12(14)$ & $74(86)$ \\
\hline $\operatorname{Tn} 21$ & 289 & 22 & 0 & $18(6)$ & $33(11)$ & $238(83)$ \\
\hline $\operatorname{Tn} 7$ & 3 & $<1$ & 0 & 0 & $1(25)$ & $2(75)$ \\
\hline \multicolumn{7}{|c|}{ Combination of genetic elements in same isolate } \\
\hline Integron + ISCR1 + Tn21 & 38 & 3 & 0 & 0 & $2(5)$ & $36(95)$ \\
\hline Integron + ISCR1 + IS 26 & 28 & 2 & 0 & 0 & $2(7)$ & $26(93)$ \\
\hline Integron + ISCR1 + ISEcp $1+\operatorname{Tn} 21$ & 16 & 1 & 0 & 0 & 0 & $16(100)$ \\
\hline No genetic element detected & 332 & 35 & $307(93)$ & $25(6)$ & 0 & 0 \\
\hline
\end{tabular}

Carriage of genetic elements or combination of elements among strains exhibiting resistance to different antimicrobials tested in this study. The antimicrobials were grouped into 8 convenient groups:- $\beta$-lactams and $\beta$-lactamase inhibitors, aminoglycosides, (fluoro)quinolones, nitrofurantoin, chloramphenicol, sulphonamides, trimethoprim, and tetracyclines. 


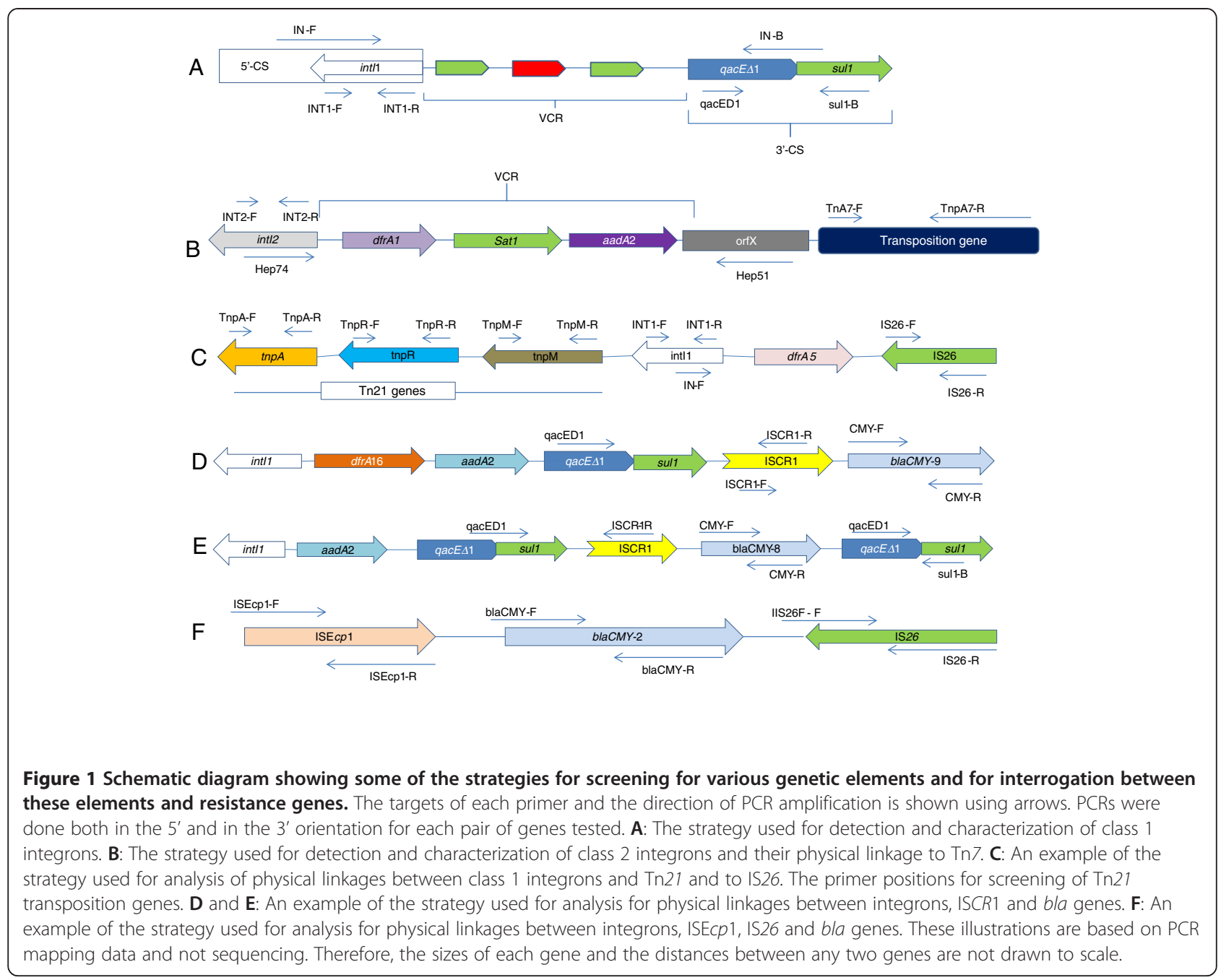

Conjugative plasmids mediate en bloc transfer of multiple elements and resistance genes

Multiple resistance genes and genetic elements associated with them were transferred en bloc to E. coli $J 53$ in mating experiments, Table 9. Majority of such transferred were mediated by plasmids containing $I 1, L / M, X I, H I 2$ and the F-type replicons. These experiments further revealed that genes conferring resistance to tetracylines and chloramphenicol were also harbored in the same plasmids encoding resistance to $\beta$-lactams, (fluoro)quinolones and aminoglycosides. However, various gene combinations that had been determined to be physically linked using PCR could not be transferred in conjugation experiments using media containing different combinations of antimicrobials.

\section{Discussion}

The current study shows that a significant proportion of clinical E. coli strains in Kenyan are resistant to important classes of antimicrobials such as $\beta$-lactams, fluoroquinolones and aminoglycosides. These results are in agreement with those published before [1,3,5]. These MDR strains were however susceptible to carbapenems. It is easy (although illegal) to purchase antimicrobials in Kenya without prescriptions or with prescriptions not backed by laboratory investigations [6]. We hypothesize that such practices may directly or indirectly lead to emergence of highly resistant strains.

A high prevalence of MDR strains from urine and all specimens from hospitalized patients may reflects a corresponding heavy use of antimicrobials among this category of patients as reported in past studies $[7,8]$. Majority of resistances encountered in hospital isolates were also encountered in community settings probably because patients are often discharged from hospitals as soon as their conditions improve, even before they complete their treatment regiments (our unpublished observations). It is therefore possible that hospital strains find their way into community settings and vis versa. However, we do not rule out the possibility that some MDR phenotypes may arise in community settings. 


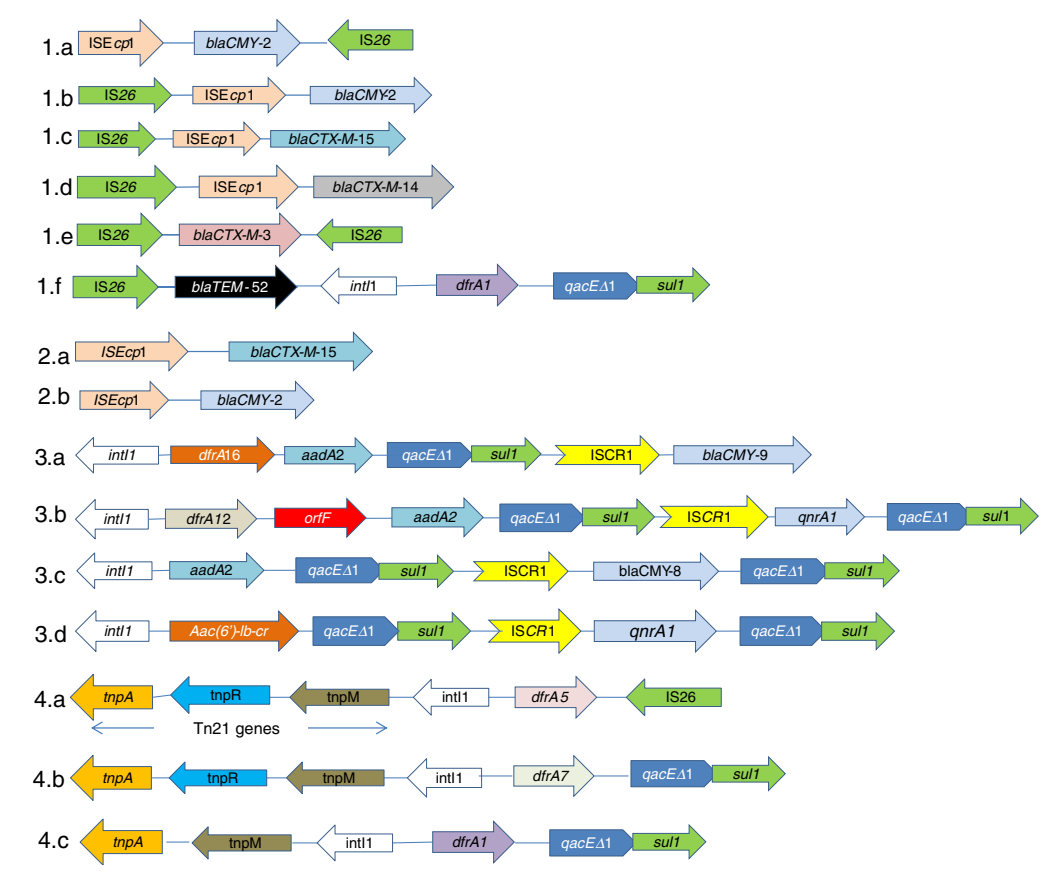

Figure 2 Schematic diagram illustrating examples of physical linkages amongst genetic elements and selected genes. 1a-1f: An example of physical linkages between bla genes and multiple genetic elements such as integrons, ISEcp1, and IS26. 2a-2b: An example of physical linkages between bla genes and ISEcp1. 3a-3d: An example of physical linkages between integrons and other genetic elements (such as the ISCR1 element) that are in turn linked to bla genes and (fluoro)quinolone resistant genes. $\mathbf{4 a - 4 c}$ : An example of physical linkages between Tn21 and integrons that are in turn be linked to IS elements. These illustrations are based on PCR mapping data and not sequencing. Therefore, the sizes of each gene and the distances between any two genes are not drawn to scale.

The high prevalence of class 1 integrons may partially be due to their association with the Tn21 that contain a complete set of transposition genes. Past studies show that $d f r A 7$ and $d f r A 1$ cassettes associated with $\operatorname{Tn} 21$ borne integrons are the most prevalent $d f r A$-subtypes in Central, North and Western Africa [9-12]. In this study however, the prevalence of $d f r A 7$ was much lower than that of $d f r A 1, d f r A 12$ and $d f A 17$ in that order. The class 2 integron $d f r A 1 /$ sat $2 /$ aad $A 1$ array reported in this study is globally distributed [13]. Our results may therefore reflect regional differences or similarities in distribution of integron cassette arrays. Such differences may arise from unique antimicrobial-use patterns in different countries. This study also demonstrates an apparent correlation between carriage of $d f r A 17$ and resistance to multiple $\beta$ - lactams as has been reported in Tunisia [12,14] and from Northern Kenya among isolates from dog, cat and human specimens [5]. The reasons behind these correlations are yet to be elucidated. Carriage of different $d f r A$ sub-types in our isolates and carriage of multiple integronassociated sul genes (sul1 and sul3) in the same isolate possibly correlates to heavy usage of sulfonamides and trimethoprim in Kenya for treatment of different infections and as prophylaxis against opportunistic infections among people with HIV/AIDS [15-17].

Some integrons, especially those lacking the 3'-CS and those containing a sul3 at the 3'-end, were linked to the IS26 possibly because this element mediates deletion of 3'-CS in class 1 integrons 3'- terminal [18,19]. Similar results have been published in Australia, Spain and Nigeria

Table 5 Physical linkages between integrons and other genetic elements

\begin{tabular}{lcccccc}
\hline & & \multicolumn{3}{c}{ Integrons (number,\%) physically linked to different elements } \\
\cline { 2 - 6 } Type of integrons & Total detected & Tn7 & Tn21 & ISCR1 & ISEcp1 & IS26 \\
\hline Class 1 integrons with 3'-CS & 375 & $3(1)$ & $257(69)$ & $199(53)$ & $19(5)$ & $4(1)$ \\
Class 1 integron with sul3 & 64 & 0 & $12(19)$ & 0 & $12(19)$ & $48(75)$ \\
Class 1 integrons lacking 3'-CS or Sul3 & 25 & 0 & $5(20)$ & 0 & $10(40)$ & $20(80)$ \\
Class 2 integron & 3 & $3(100)$ & $1(33)$ & $1(33)$ & $1(33)$ & 0 \\
\hline
\end{tabular}

Carriage of Tn21, Tn7 and IS elements among strains carrying class 1 integrons. Carriage of other genetic elements among strains carrying class 2 integrons is also shown. 
Table 6 Carriage of transposition genes among Tn21 transposons

\begin{tabular}{|c|c|c|c|c|}
\hline \multirow[b]{2}{*}{ Category of $\operatorname{Tn} 21$} & \multirow[b]{2}{*}{ Number of Tn21 detected } & \multicolumn{3}{|c|}{ Number (\%) of Tn21 transposition gene combination } \\
\hline & & tnpA + tnpM only & tnpR + tnpM only & $\operatorname{tnp} M+\operatorname{tnp} A+\operatorname{tnpR}$ \\
\hline Tn21 linked to integrons & 156 & 0 & $9(6)$ & $147(94)$ \\
\hline Tn21 not linked to integrons & 133 & $56(42)$ & $63(47)$ & $14(11)$ \\
\hline
\end{tabular}

PCR methods were used for screening for three genes that are crucial for transposition of Tn21. The tnpA encodes a Tn21-like transposase, the tnpM encodes a putative transposition regulator. Integrons are incorporated into the $\mathrm{Tn} 21$ framework adjacent to the tnpM gene. The tnpR encodes a resolvase.

$[11,12,18,19]$. Our data further suggest that strains carrying IS26-associated integrons are highly MDR probably because the IS26 is also linked to other non-integron genes such as $\beta$-lactamases.

Most $\beta$-lactamases, particularly those encoding CTX-M -14 and -15 and CMY-2, were physically linked to ISEcp 1 . Similar reports have been published in Tunisian $[20,21]$ but no ISE $c p 1$ was detected upstream the bla-CTX-M-1 among our isolates as reported in a related study from the same country [22]. In one isolate, this element was found upstream the $b l a_{C T X-M-9}$. Reports of ISEcp1-bla $a_{C T X-M-9}$ linkages are rare but such linkages have been reported in Klebsiella pneumoniae isolates in Taiwan [23]. Majority of bla $a_{T E M}$ genes, bla $a_{T E M-52}$ in particular, were physically

Table 7 Analysis for physical association between bla genes and various genetic elements

\begin{tabular}{|c|c|c|c|c|c|}
\hline \multirow[b]{2}{*}{$\begin{array}{l}\beta \text {-lactamase } \\
\text { genes }\end{array}$} & \multirow[b]{2}{*}{$\begin{array}{l}\text { Number of } \\
\text { isolates tested }\end{array}$} & \multicolumn{4}{|c|}{$\begin{array}{l}\text { Number (\%) of } \beta \text {-lactamase physically } \\
\text { linked to various genetic elements }\end{array}$} \\
\hline & & IS26 & ISEcp 1 & ISCR1 & Integrons \\
\hline$\overline{b l a} a_{S H V-1}$ & 60 & $23(38)$ & $12(20)$ & $10(17)$ & $9(15)$ \\
\hline$b l a_{O X A-1}$ & 43 & $12(28)$ & $21(49)$ & $32(74)$ & $36(84)$ \\
\hline bla $a_{X A-2}$ & 17 & 0 & $2(12)$ & $5(29)$ & $3(18)$ \\
\hline$b l a_{S H V-5}$ & 18 & $10(55)$ & $5(28)$ & $3(17)$ & $1(6)$ \\
\hline$b a_{S H V-12}$ & 19 & $7(37)$ & $4(21)$ & $3(16)$ & $2(11)$ \\
\hline$b l a_{C T X-M-1}$ & 9 & $1(11)$ & 0 & $2(22)$ & $1(11)$ \\
\hline$b l a_{C T X-M-3}$ & 15 & $6(40)$ & 0 & 0 & 0 \\
\hline$b l a_{C T X-M-8}$ & 6 & $2(33)$ & $1(17)$ & 0 & 0 \\
\hline$b l a_{C T X-M-9}$ & 3 & 0 & $1(33)$ & $3(100)$ & 0 \\
\hline bla $a_{C T X-M-14}$ & 25 & $10(40)$ & $3(12)$ & $5(20)$ & $3(12)$ \\
\hline$b^{b l a} a_{C T X-M-15}$ & 32 & $4(13)$ & 30 (94) & 0 & 0 \\
\hline$b / a_{T E M-103}$ & 18 & $2(11)$ & 0 & $1(6)$ & $1(6)$ \\
\hline bla $a_{T E M-109}$ & 9 & 0 & 0 & 0 & 0 \\
\hline$b^{b} a_{T E M-50}$ & 10 & $2(20)$ & $1(10)$ & $6(60)$ & $3(30)$ \\
\hline$b / a_{\mathrm{TEM}-52}$ & 37 & 29 (78) & $1(3)$ & $3(8)$ & $2(5)$ \\
\hline$b a_{T E M-78}$ & 9 & $2(22)$ & 0 & $3(33)$ & $2(22)$ \\
\hline bla $a_{T E M-125}$ & 36 & $3(8)$ & 0 & $3(8)$ & $2(6)$ \\
\hline$b a_{T E M-152}$ & 14 & $1(7)$ & 0 & $4(29)$ & $2(14)$ \\
\hline$b l a_{T E M-158}$ & 10 & $1(10)$ & 0 & 0 & 0 \\
\hline$b / a_{C M Y-2}$ & 48 & $12(25)$ & $42(88)$ & $12(25)$ & $3(6)$ \\
\hline
\end{tabular}

Analysis for physical linkages between bla genes and various genetic elements. The bla content of the isolates analyzed had been determined in a past study [3]. linked to the IS26 as reported in Belgium and Germany $[24,25]$. Taken together, these results suggest that most bla genes in our isolates are in similar genetic environments as those reported globally but the genetic environment of $b l a_{C T X-M-9}$ and $b l a_{C T X-M-1}$ in our isolates appears to be different from those reported globally.

Our results further demonstrated that most bla genes are distantly linked to elements that are in turn linked to other resistance genes such as aac(6')-lb-cr and qur. Similar reports have been published in Tunisia [20,21] and in Nigeria [11]. ISE $c p 1$, IS26 and ISCR 1 are known to mediate transposition and/or expression of multiple resistance genes in their close proximity [26-31]. Carriage of such multiple elements, each carrying a set of resistance genes may be responsible for the observed coresistance to multiple antimicrobials among our isolates.

Conjugation experiments confirmed that multiple elements were borne on narrow host-range plasmids such as IncFII, IncH12 or on broad host-range plasmids such as $I n c L / M$. The type of conjugative plasmids in our isolates (especially those carrying plasmids containing incFtype, incHI2 and incI1 incL/M replicons) were shown to confer resistances similar to those in strains from Tunisia, [32] and from two other studies conducted in Kenya [1,5]. We hypothesis that plasmids of different incompatibility groups have acquired similar or identical sets of resistance genes and this acquisition is mediated by genetic elements such as those investigated in this study. Therefore, there is a possibility that such elements act as genetic shuttles between plasmids of different incompatibility grouping. The similarities and differences in genetic environments of bla, aac (6')-lb-cr and $q n r$ genes reported in this study may reflect a difference in transposition activities of such elements. We further hypothesize that differences in antibiotic use patterns in different regions influence the transposition activity of such elements.

\section{Conclusions}

This study reports carriage of multiple genetic elements in MDR E. coli strains and their association with selected resistance genes. Strains carrying such elements are likely to be well adapted to survive deleterious effects of combined antimicrobial therapy. Furthermore, such MDR strains have a potential to increase morbidity and mortality among patients. It is therefore important to launch 
Table 8 Carriage of $a a c\left(6^{\prime}\right)-l b-c r$ and $q n r$ genes among strains containing genetic elements and bla genes

\begin{tabular}{|c|c|c|c|c|c|c|c|c|c|c|c|c|}
\hline & \multirow[b]{2}{*}{ Total } & \multicolumn{8}{|c|}{$\begin{array}{l}\text { Number (\%) of strains carrying each gene and number } \\
\text { (\%) of strains containing genes linked to genetic elements }\end{array}$} & \multicolumn{3}{|c|}{$\begin{array}{l}\text { Occurrence in strains } \\
\text { carrying bla genes }^{\mathrm{a}}\end{array}$} \\
\hline & & $\begin{array}{c}\text { Strains } \\
\text { containing } \\
\text { int/1 }\end{array}$ & $\begin{array}{l}\text { Linked } \\
\text { to int/1 }\end{array}$ & $\begin{array}{c}\text { Strains } \\
\text { containing } \\
\text { IS26 }\end{array}$ & $\begin{array}{l}\text { Linked } \\
\text { to IS26 }\end{array}$ & $\begin{array}{c}\text { Strains } \\
\text { containing } \\
\text { ISCR1 }\end{array}$ & $\begin{array}{l}\text { Linked } \\
\text { to ISCR1 }\end{array}$ & $\begin{array}{c}\text { Strains } \\
\text { containing } \\
\text { ISEcp1 }\end{array}$ & $\begin{array}{l}\text { Linked } \\
\text { to ISEcp1 }\end{array}$ & $\begin{array}{c}\beta \text {-lactamase } \\
\text { negative } \\
\text { strains }\end{array}$ & $\begin{array}{c}\text { Strains } \\
\text { containing } \\
\text { TEM-1 or } \\
\text { SHV-1 only }\end{array}$ & $\begin{array}{c}\text { Strains } \\
\text { containing } \\
\text { broad-spectrum } \\
\text { bla genes }\end{array}$ \\
\hline$a a c\left(6^{\prime}\right)-l b-c r$ & 42 & $42(100)$ & $42(100)$ & $6(14)$ & $4(9)$ & $12(29)$ & $6(14)$ & $11(26)$ & $4(10)$ & 0 & $4(9)$ & $38(91)$ \\
\hline$q n r A$ & 34 & $27(79)$ & $26(75)$ & $11(32)$ & $4(12)$ & $28(82)$ & $23(68)$ & $8(24)$ & $1(3)$ & 0 & $2(6)$ & $32(94)$ \\
\hline$q n r B$ & 19 & $19(100)$ & $11(58)$ & $10(53)$ & $2(11)$ & $13(64)$ & $4(21)$ & $12(63)$ & $1(5)$ & 0 & $1(5)$ & $18(95)$ \\
\hline
\end{tabular}

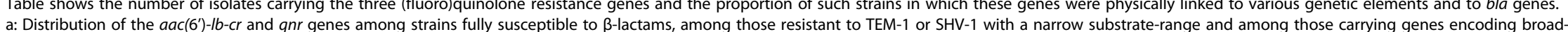
spectrum $\beta$-lactamases such as bla $a_{S H V-5}, b / a_{S H V-12}, b l a_{C M Y}$ and bla ${ }_{C T X-M S}$. 
Table 9 Horizontal transfer of genetic elements and associated resistance genes from clinical strains (donors) to E. coli J53 (recipient)

\begin{tabular}{|c|c|c|c|}
\hline \multicolumn{4}{|l|}{ Resistance profiles among donor and transconjugants } \\
\hline Resistance to selected antimicrobials among donors & $\begin{array}{l}\text { Physically linked genetic elements or resistance genes } \\
\text { detected in donors and recipients }\end{array}$ & $\begin{array}{l}\text { Other genes whose linkages were } \\
\text { not determined }\end{array}$ & Plasmid replicons detected \\
\hline AMP, CTX, CAZ, FOX, NA, CIP, TET, C, AMC, K, CN, SUL & ISEcp1/bla ${ }_{C M Y-2} /$ IS26 & aadA1, bla $a_{S H V-12}$ & $P, \mathbf{I 1}$ \\
\hline AMP, CTX, CAZ, FOX, NA, CIP, TET, C, AMC, K, CN, SUL & IS26/ISEcp $1 / \mathrm{b} / a_{C M Y-2}, q n r A 1$ & $\operatorname{Tn} 21$, dra5, sul1 & $\mathrm{L} / \mathrm{M}$ \\
\hline AMP, CTX, CAZ, NA, TET, C, AMC, K, CN, SUL, TRIM & IS26/ISEcp $1 / b l a_{C T X-M-15}$ & $\operatorname{Tn} 21, d f r A 1, a a c\left(6^{\prime}\right) / b$ & FII, F, A/C \\
\hline AMP, CTX, CAZ, NA, TET, C, AMC, K, CN, SUL, TRIM & IS26/ISEcp1/bla CTX-M-14 & Tn21, aadA5, sul1, blaTEM-1 & $\mathrm{A} / \mathrm{C}, \mathbf{K}, \mathrm{B} / \mathrm{O}$ \\
\hline AMP, CTX, CAZ, NA, TET, C, AMC, K, CN, SUL, TRIM & IS26/bla $a_{C T X-M-3} / I S 26$ & $\operatorname{aac}\left(6^{\prime}\right) \mid b, a n r B$ & FII, F \\
\hline AMP, CTX, CAZ, NA, TET, C, AMC, K, CN, SUL, TRIM & IS26/bla ${ }_{T E M-52} /$ intl1/dfrA1/qacE $\Delta 1 /$ sul1 & $b l a_{T E M-1}$ & I1, FIB \\
\hline AMP, CTX, CAZ, NA, CIP, TET, C, AMC, K, CN, SUL, TRIM & ISEcP1/bla CTX-M-15 & $d f r A 12$, aadA1, bla $a_{O X A-1} b l a_{T E M-1}$, sul3 & $\mathrm{XI}$ \\
\hline AMP, CTX, CAZ, FOX, NA, CIP, TET, C, AMC, K, CN, SUL & ISEcp $1 / b l a_{C M Y-2} /$ int/1/aac(6')-Ib-cr/SCR1/qnrA1 & $\operatorname{aac}\left(6^{\prime}\right) \mid b, c a t B 3, d f r A 1$ & $\mathrm{~L} / \mathrm{M}, \mathrm{K}$ \\
\hline AMP, CTX, CAZ, NA, CIP, TET, C, AMC, K, CN, SUL, TRIM & int/1/dfrA16/aadA2/qacEA1/sul1/ISCR1/bla CTX-M-9 & $b l a_{T E M-1}, b l a_{S H V-5}$ & L/M \\
\hline AMP, CTX, CAZ, NA, CIP, TET, C, AMC, K, CN, SUL, TRIM & int11/dfrA12/orfF/aadA2/qacED1/sul1/ISCR1/qnrA/qacEA1/sul1 & blactX-M-15, bla $a_{T E M-1}$, bla OXA-1 & I1, FIB \\
\hline AMP, CTX, CAZ, FOX, NA, CIP, TET, C, AMC, K, CN, SUL & 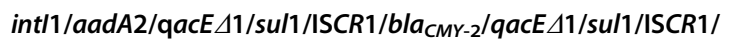 & qnrA1, & $\mathbf{I 1}, \mathrm{K}, \mathrm{B} / \mathrm{O}$ \\
\hline AMP, CTX, CAZ, NA, CIP, TET, C, AMC, K, CN, TRIM SUL & intl1/aac(6')-lb-cr/qacEA1/sul1/qnrA1/qacE $\Delta 1 /$ sul1 & $b l a_{T E M-1}, b l a_{S H V-5}$ & FIA, FIB \\
\hline AMP, CTX, NA, CIP, TET, C, AMC, K, CN, SUL, TRIM & Tn21/int/1/dfrA5/IS26 & $b l a_{T E M-125}$ & $\mathrm{FIB}, \mathrm{F}, \mathrm{HI} \mathbf{2}$ \\
\hline AMP, CTX, NA, CIP, TET, C, AMC, K, CN, SUL, TRIM & Tn21/int/1/dfrA7/qacEA1/sul1 & $b l a_{C T X-M-8}$ & $\mathrm{I1}, \mathrm{F}$ \\
\hline AMP, CTX, CAZ, NA, CIP, TET, C, AMC, K, CN, SUL, TRIM & Tn21/int/1/dfrA1/qacEA1/sul1 & $b / a_{T E M-15}, b a_{T E M-1}, b l a_{O X A-1}, \operatorname{aac}\left(6^{\prime}\right)-1 b-c r$ & $\mathrm{FIB}, \mathrm{HI} 2$ \\
\hline
\end{tabular}

AMP, CTX, CAZ, NA, CIP, TET, C, AMC, K, CN, SUL, TRIM Tn21/int/1/dfrA1/qacE $1 /$ sul1 transconjugants are indicated in bold. 
Table 10 Primers for screening for genetic elements and resistance genes and for analysis for physical linkages among such elements and selected resistance genes

\begin{tabular}{|c|c|c|c|c|c|}
\hline Target Gene/region & Primer name & 5'-3' sequence & $\begin{array}{c}\text { Annealing } \\
\text { Temperature }\end{array}$ & $\begin{array}{l}\text { Expected product } \\
\text { size (bp) } \\
\end{array}$ & $\begin{array}{c}\text { Gene accession } \\
\text { Number }\end{array}$ \\
\hline \multicolumn{6}{|l|}{ Integrons } \\
\hline \multirow[t]{2}{*}{ int/1 } & INT-1 F & GTTCGGTCAAGGTTCTG & 50 & 923 & U12338 \\
\hline & INT-1R & GCCAACTITCAGCACATG & & & \\
\hline \multirow[t]{2}{*}{ int $/ 2$} & INT-2 F & ATGTCTAACAGTCCATTTT & 50 & 450 & AJ001816.1 \\
\hline & INT-2R & AAATCTTTAACCCGCAAAC & & & \\
\hline \multirow[t]{2}{*}{ int/3 } & INT3-F & GCAGGGTGTGGACGAATACG & 57 & 760 & AY219651 \\
\hline & INT3-R & ACAGACCGAGAAGGCTTATG & & & \\
\hline \multirow[t]{2}{*}{$3^{\prime}-\mathrm{CS}$} & qacED1 & ATCGCAATAGTTGGCGAAGT & 56 & 800 & X15370 \\
\hline & sul1-B & GCAAGGCGGAAACCCGCGCC & & & X12869 \\
\hline \multirow[t]{2}{*}{ integron class 1 VCR } & $\ln -\mathrm{F}$ & GGCATACAAGCAGCAAGC & 52 & Variable & U12338 \\
\hline & $\ln -B$ & AAGCAGACTTGACCTGAT & & & \\
\hline \multirow[t]{2}{*}{ integron 2 VCR } & hep74 & CGGGATCCCGGACGGCATGCACGATTTGTA & 55 & Variable & EU780012 \\
\hline & hep51 & GATGCCATCGCAAGTACGAG & & & AJ002782 \\
\hline \multicolumn{6}{|l|}{ IS elements } \\
\hline \multirow[t]{2}{*}{$|S E c p|$} & ISEcp1-F & GTT GCT CTG TGG ATA ACT TG & 55 & 180 & AJ242809 \\
\hline & ISEcp1-R & CCT AAA TTC CAC GTG TGT & & & \\
\hline \multirow[t]{2}{*}{$\mid S C R 1$} & ISCR1-F & CGC CCA CTC AAA CAA ACG & 55 & 469 & L06418 \\
\hline & ISCR1-R & GAG GCT TTG GTG TAA CCG & & & \\
\hline \multirow[t]{2}{*}{ IS26 } & IS26-F & GCGGTAAATCGTGGAGTGAT & 55 & 704 & NC 007941.1 \\
\hline & IS26-R & ATTCGGCAAGTTITTGCTGT & & & \\
\hline \multicolumn{6}{|l|}{ Tn21 and Tn7 } \\
\hline \multirow[t]{2}{*}{ tnpM of $\operatorname{Tn} 21$} & TnpM-F & TCAACCTGACGGCGGCGA & 55 & 348 & AF071413 \\
\hline & TnpM-R & GGAGGTGGTAGCCGAGG & & & \\
\hline \multirow[t]{2}{*}{$\operatorname{tnp} R$ of $\operatorname{Tn} 21$} & TnpR-F & GTC AGC AGC TTC GAC CAG AA & 62 & 500 & NC 002134.1 \\
\hline & TnpR-R & GAG GTA CTG GTA GAG GGT TT & & & \\
\hline \multirow[t]{2}{*}{ tnpA of $\operatorname{Tn} 21$} & TnpA21-F & TGC GCT CCG GCG ACA TCT GG & 62 & 1200 & NC 002134.1 \\
\hline & TnpA21-R & TCA GCC CGG CAT GCA CGC G & & & \\
\hline \multirow[t]{2}{*}{$\operatorname{tnp} A$ of $\mathrm{Tn} 7$} & TnA7-F & CCCAGCAATAAAAGAGCTCATTGAGCAAGC & 55 & 738 & FJ914220.1 \\
\hline & TnA7-R & TATCTAGAAACAGAGTGTCTTG & & & \\
\hline \multicolumn{6}{|c|}{ (fluoro)quinolone resistance genes } \\
\hline \multirow[t]{2}{*}{ qnrA } & qnrA-F & TTCAGCAAGAGGATTTCTCA & 55 & 627 & AY070235 \\
\hline & qnrA-R & GGCAGCACTATTACTCCCAA & & & \\
\hline \multirow[t]{2}{*}{$q n r B$} & qnrB-F & CCTGAGCGGCACTGAATTTAT & 60 & 408 & DQ351241 \\
\hline & qnrB-R & GTTGCTGCTCGCCAGTCGA & & & \\
\hline \multirow[t]{2}{*}{ anrs } & qnrS-F & CAATCATACATATCGGCACC & 60 & 641 & AB187515 \\
\hline & qnrS-R & TCAGGATAAACAACAATACCC & & & \\
\hline \multirow[t]{3}{*}{$\operatorname{aac}\left(6^{\prime}\right)-1 b-c r$} & aac $\left(6^{\prime}\right)-\mathrm{Ib}-\mathrm{Cr}-\mathrm{F}$ & TTGCGATGCTCTATGAGTGGCTA & 55 & 482 & AAL93141.1 \\
\hline & $\mathrm{aac}\left(6^{\prime}\right)-\mathrm{lb}-\mathrm{cr}-\mathrm{R}$ & CTCGAATGCCTGGCGTGTTT & & & \\
\hline & aac(6')-Ib-cr (sequencing) & CGTCACTCCATACATTGCAA & & & \\
\hline \multicolumn{6}{|l|}{ bla genes } \\
\hline \multirow[t]{2}{*}{ blaTEM } & TEM-F & ATGAGTATTCAACAT TTC CG & 55 & 840 & EF125012 \\
\hline & TEM-R & CCAATGCTTAATCAG TGA GG & & & \\
\hline
\end{tabular}


Table 10 Primers for screening for genetic elements and resistance genes and for analysis for physical linkages among such elements and selected resistance genes (Continued)

\begin{tabular}{|c|c|c|c|c|c|}
\hline \multirow[t]{2}{*}{ blaSHV } & SHV-F & TTCGCCTGTGTATTATCTCCCTG & 50 & 854 & AF148850 \\
\hline & SHV-R & TTAGCGTTGCCAGTGYTCG & & & \\
\hline \multirow[t]{2}{*}{ blactX-M } & CTX-M-F & ATGTGCAGYACCAGTAARGTKATGGC & 60 & 593 & Y10278 \\
\hline & CTX-m-R & TGGGTRAARTARGTSACCAGAAYCAGCGG & & & \\
\hline \multirow[t]{2}{*}{ blaCMY } & CMY-F & ATGATGAAAAAATCGTTATGC & 55 & 1200 & U77414 \\
\hline & CMY-R & TTGCAGCTITCAAGAATGCGC & & & \\
\hline \multirow[t]{2}{*}{ blaOXA-1 } & OXA-1 F & ATGAAAAACACAATACATATCAACTTCGC & 62 & 820 & JO2967 \\
\hline & OXA-1R & GTGTGTTTAGAATGGTGATCGCATT & & & \\
\hline \multirow[t]{2}{*}{ blaOXA-2 } & OXA-2 F & ACGATAGTTGTGGCAGACGAAC & 62 & 602 & AF300985 \\
\hline & OXA-2R & ATYCTGTTTGGCGTATCRATATTC & & & \\
\hline
\end{tabular}

Primers used for screening various genetic elements and for interrogating physical linkages between different genetic elements and between such elements and bla genes or (fluoro)quinolone resistance genes.

$\mathrm{Y}=\mathrm{T}$ or $\mathrm{C}, \mathrm{R}=\mathrm{G}$ or $\mathrm{A}, \mathrm{S}=\mathrm{G}$ or $\mathrm{C}, \mathrm{K}=\mathrm{G}$ or $\mathrm{T}$.

surveillance programs and to put up measures to curtail the spread of these highly resistant strains. There is also a need to compare the genomes of strains encountered in Africa with those from other parts of the world.

\section{Methods}

\section{Isolates}

The 1327 non-duplicate isolates were obtained sequentially from 13 healthcare facilities in Kenya between 1992 and 2011 (19-year period) from 654 hospitalized and 673 non-hospitalized patients. These isolates comprised of 451 strains from patients with urethral tract infections (UTI) and those with urinary catheters while 371 were from blood of patients with septicemia. Another 505 strains were from fecal specimens of patients with loose stool, watery and bloody diarrhea. Only one isolate per specimen per patient was included for further analysis. Among the isolates investigated in this study, 912 had been analyzed for bla genes in a a past study [3] while 27 had been analyzed for selected genetic elements [1]. Ethical clearance to carry out this study was obtained from the KEMRI/National Ethics Committee (approval number SSC No. 1177).

\section{Antimicrobial susceptibility profiles}

Susceptibility profiles for all isolates were determined using antibiotic discs (Cypress diagnostics, Langdorp, Belgium) on Mueller Hinton agar (Oxoid, Louis, Mo. USA) using the Laboratory Standards Institute guidelines (CLSI) [33].

\section{Detection of genetic elements}

Figure 1 illustrates the strategy used for detection and characterization of integrons and transposons. Detection of class 1, 2 and 3 and determination of carriage of 3'conserved sequences (3'-CS) in class 1 integrons was done as described before [34,35]. Class 1 integron variable cassette region (VCR), the region in which the resistance gene cassettes are integrated, was amplified as previously described by Dalsgaard et al. [35] while that of class 2 integrons was amplified as described by White et al. [36]. The VCRs of integrons lacking the typical 3'CS was determined using a PCR walking strategy published before [37]. Identification of integron cassette identity was done using a combination of restriction fragment length polymorphism (RFLP), sequencing and published bioinformatics tools [38,39]. Detection of the ISEcp 1, ISCR1, Tn21 and Tn7 elements was done as described in published studies [34,35]. Analysis for $\operatorname{Tn} 21$ transposition genes:- tnpA, tпpR and tnpM genes was done as previously described by Pearson et al. [40]. The primers used in this study are presented in Table 10.

\section{Detection of $\operatorname{aac}\left(6^{\prime}\right)-\mathrm{lb}-\mathrm{cr}$ and $q \mathrm{q} r$ genes}

Screening for $a a c\left(6^{\prime}\right)-I b-c r$ gene that confers crossresistance to fluoroquinolones and aminoglycoside was done using a combination of PCR, RFLP and sequencing as described by Park et al. [41]. The isolates were also screened for genes conferring resistance to quinolones: - qnrA, qnrB and qnrS using PCR and sequencing strategies previously described by Wu et al. [42].

\section{Interrogation for physical linkages between genetic elements and resistance genes}

Physical linkages between integron and the transposons were determined using a combination of published primers targeting 5'-conserved sequences (5'-CS) of class 1 integrons and those targeting the tnpM of $\operatorname{Tn} 2$ or those specific for $\operatorname{tnp} A 7$ of $\operatorname{Tn} 7$, Figure 1. A combination of primers targeting IS elements and those targeting the 5'CS or the 3'-termini of integrons were used for interrogation for physical linkages between integrons and IS elements. A combination of primers specific for various genetic elements and consensus primers for $b l a_{S H V}$ or bla $_{T E M,}[43,44]$, bla $_{C T X-M}[45], b l a_{C M Y}[46]$ and bla ${ }_{O X A}$ 
$[47,48]$ were used for determination of physical linkages between bla genes and different genetic elements. Primers for $a a c\left(6^{\prime}\right)-l b-c r$ and $q n r$ genes were used in combination with those for different genetic elements to analyze for their physical association. A long-range polymerase [LongAmp ${ }^{\circledR}$ Taq DNA Polymerase, (New England Biolabs, USA)] was used in all reactions for physical linkages. A slow ramping rate of between $0.2^{\circ} \mathrm{C} / \mathrm{sec}$ and $0.3^{\circ} \mathrm{C} / \mathrm{sec}$ was set for the annealing step. The extension time was set at $72^{\circ} \mathrm{C}$ for $2 \mathrm{~min}$ and a final extension of $72^{\circ} \mathrm{C}$ for $15 \mathrm{~min}$ was carried out after 35-40 cycles of denaturation, annealing and extension.

\section{Conjugation experiments}

Conjugation experiments using sodium azide resistant $E$. coli strain $J 53$ as the recipient were done as previous described [49]. Susceptibility to antimicrobials and determination of genetic element content of the transconjugants was determined using similar methods as those used for the corresponding donor strains. Plasmid incompatibility groupings were determined using the scheme of Carattoli et al. [50].

\section{Statistical analysis}

For the purpose of analysis, both intermediate and resistant results for antibiotic susceptibility testing were grouped together as "resistant". Differences in proportion of isolates bearing different elements was analyzed using the Chi test $\left(\chi^{2}\right)$ while the Fisher's exact test was used for smaller sample sizes. The Odds Rations (OR) and the 95\% confidence intervals (CIs) accompanying the $\chi 2$ tests were determined using the approximation of Woolf. The null hypothesis was rejected for values of $p \geq 0.05$. Statistical analysis was performed using Statgraphics plus Version 5 (StatPoint Technologies, INC, Warrenton, VA, USA).

\section{Competing interests}

None of the authors have competing interests.

\section{Authors' contributions}

JK designed the study, carried out the experiments and wrote the manuscript. SK, BM and PB participated in manuscript write-up and review. All authors read and approved the final manuscript.

\section{Authors' information}

JK and SK are research scientists at the Kenya Medical Research Institute (KEMRI). BMG is Professor at the K.U.Leuven (Faculty of Bioscience Engineering) while PB is a Senior Research Scientist at the Veterinary and Agrochemical Research Centre (VAR).

\section{Acknowledgements}

The authors would like to thank staff and students attached to the CMR-WT unit lab at KEMRI and staff members of Bacteriology unit at VAR-Belgium. This work was supported by a PhD scholarship grant from the Vlaamse Interuniversitaire Raad (VLIR), Belgium (Grant number BBTP2007-0009-1086). This work is published with permission from the Director, KEMRI.

\section{Author details}

'Centre for Microbiology Research, Kenya Medical Research Institute, PO Box 19464-00202, Nairobi, Kenya. ${ }^{2}$ Department of Biosystems, Faculty of
Bioscience Engineering, Katholieke Universiteit Leuven, Kasteelpark Arenberg 30, B-3001, Heverlee, Belgium. ${ }^{3}$ Veterinary and Agrochemical Research Centre, Groeselenberg 99, B-1180, Ukkel, Belgium. ${ }^{4}$ Department of Pathology, Bacteriology and Poultry Diseases, Faculty of Veterinary Medicine, University of Ghent, Salisburylaan 133, 9820, Merelbeke, Belgium. ${ }^{5}$ Department of Virology, Parasitology and Immunology, Faculty of Veterinary Medicine, University of Ghent, Salisburylaan 133, 9820, Merelbeke, Belgium.

Received: 24 September 2012 Accepted: 10 May 2013

Published: 17 May 2013

\section{References}

1. Kiiru J, Kariuki S, Goddeeris BM, Revathi G, Maina TW, Ndegwa DW, Muyodi J, Butaye P: Escherichia coli strains from Kenyan patients carrying conjugatively transferable broad-spectrum beta-lactamase, qnr, aac(6')$\mathrm{Ib}-\mathrm{cr}$ and 16S rRNA methyltransferase genes. J Antimicrob Chemother 2011, 66:1639-1642.

2. Kariuki S, Revathi G, Corkill J, Kiiru J, Mwituria J, Mirza N, Hart CA Escherichia coli from community-acquired urinary tract infections resistant to fluoroquinolones and extended-spectrum beta-lactams. J Infect Dev Ctries 2007, 1:257-262.

3. Kiiru J, Kariuki S, Goddeeris BM, Butaye P: Analysis of beta-lactamase phenotypes and carriage of selected beta-lactamase genes among Escherichia coli strains obtained from Kenyan patients during an 18-year period. BMC Microbiol 2012, 12:155.

4. Sabate M, Navarro F, Miro E, Campoy S, Mirelis B, Barbe J, Prats G: Novel complex sul1-type integron in Escherichia coli carrying bla(CTX-M-9). Antimicrob Agents Chemother 2002, 46:2656-2661.

5. Albrechtova K, Dolejska M, Cizek A, Tausova D, Klimes J, Bebora L, Literak I: Dogs of nomadic pastoralists in northern Kenya are reservoirs of plasmid-mediated cephalosporin- and quinolone-resistant Escherichia coli, including pandemic clone B2-O25-ST131. Antimicrob Agents Chemother 2012, 56:4013-4017.

6. Brooks JT, Shapiro RL, Kumar L, Wells JG, Phillips-Howard PA, Shi YP, Vulule JM, Hoekstra RM, Mintz E, Slutsker L: Epidemiology of sporadic bloody diarrhea in rural Western Kenya. Am J Trop Med Hyg 2003, 68:671-677.

7. Blango MG, Mulvey MA: Persistence of uropathogenic Escherichia coli in the face of multiple antibiotics. Antimicrob Agents Chemother 2010, 54:1855-1863.

8. Bejon P, Mwangi I, Ngetsa C, Mwarumba S, Berkley JA, Lowe BS, Maitland K, Marsh K, English M, Scott JA: Invasive Gram-negative bacilli are frequently resistant to standard antibiotics for children admitted to hospital in Kilifi, Kenya. J Antimicrob Chemother 2005, 56:232-235.

9. Frank T, Gautier V, Talarmin A, Bercion R, Arlet G: Characterization of sulphonamide resistance genes and class 1 integron gene cassettes in Enterobacteriaceae, Central African Republic (CAR). J Antimicrob Chemother 2007, 59:742-745

10. Gassama A, Aidara-Kane A, Chainier D, Denis F, Ploy MC: Integronassociated antibiotic resistance in enteroaggregative and enteroinvasive Escherichia coli. Microb Drug Resist 2004, 10:27-30.

11. Labar AS, Millman JS, Ruebush E, Opintan JA, Bishar RA, Aboderin AO, Newman MJ, Lamikanra A, Okeke IN: Regional dissemination of a trimethoprim-resistance gene cassette via a successful transposable element. PLoS One 2012, 7:e38142.

12. Dahmen S, Mansour W, Boujaafar N, Arlet G, Bouallegue O: Distribution of cotrimoxazole resistance genes associated with class 1 integrons in clinical isolates of Enterobacteriaceae in a university hospital in Tunisia. Microb Drug Resist 2010, 16:43-47.

13. Goldstein C, Lee MD, Sanchez S, Hudson C, Phillips B, Register B, Grady M, Liebert C, Summers AO, White DG, Maurer JJ: Incidence of class 1 and 2 integrases in clinical and commensal bacteria from livestock, companion animals, and exotics. Antimicrob Agents Chemother 2001, 45(3):723-726.

14. Ben SK, Jouini A, Ben SR, Somalo S, Saenz Y, Estepa V, Boudabous A, Torres C: Prevalence of broad-spectrum cephalosporin-resistant Escherichia coli isolates in food samples in Tunisia, and characterization of integrons and antimicrobial resistance mechanisms implicated. Int J Food Microbiol 2010, 137:281-286

15. Grape M, Farra A, Kronvall G, Sundstrom L: Integrons and gene cassettes in clinical isolates of co-trimoxazole-resistant Gram-negative bacteria. Clin Microbiol Infect 2005, 11:185-192. 
16. White PA, Mclver CJ, Rawlinson WD: Integrons and gene cassettes in the enterobacteriaceae. Antimicrob Agents Chemother 2001, 45:2658-2661.

17. Bennett PM: Integrons and gene cassettes: a genetic construction kit for bacteria. J Antimicrob Chemother 1999, 43(1):1-4.

18. Curiao T, Canton R, Garcillan-Barcia MP, de la Cruz F, Baquero F, Coque TM: Association of composite IS26-sul3 elements with highly transmissible Incl1 plasmids in extended-spectrum-beta-lactamase-producing Escherichia coli clones from humans. Antimicrob Agents Chemother 2011, 55:2451-2457

19. Dawes FE, Kuzevski A, Bettelheim KA, Hornitzky MA, Djordjevic SP, Walker MJ: Distribution of class 1 integrons with IS26-mediated deletions in their 3'-conserved segments in Escherichia coli of human and animal origin. PLoS One 2010, 5:e12754.

20. Ben SK, Ben SR, Jouini A, Rachid S, Moussa L, Saenz Y, Estepa V, Somalo S, Boudabous A, Torres C: Diversity of genetic lineages among CTX-M-15 and CTX-M-14 producing Escherichia coli strains in a Tunisian hospital. Curr Microbiol 2011, 62:1794-1801.

21. Jouini A, Ben SK, Vinue L, Ruiz E, Saenz Y, Somalo S, Klibi N, Zarazaga M, Ben MM, Boudabous A, Torres C: Detection of unrelated Escherichia coli strains harboring genes of CTX-M-15, OXA-1, and AAC(6')-Ib-cr enzymes in a Tunisian hospital and characterization of their integrons and virulence factors. J Chemother 2010, 22:318-323.

22. Ben SR, Ben SK, Estepa $V$, Jouini A, Gharsa H, Klibi N, Saenz Y, Ruiz-Larrea F, Boudabous A, Torres C: Prevalence and characterisation of extendedspectrum beta-lactamase (ESBL)-producing Escherichia coli isolates in healthy volunteers in Tunisia. Eur J Clin Microbiol Infect Dis 2012, 31:1511-1516.

23. Ma L, Siu LK, Lu PL: Effect of spacer sequences between bla(CTX-M) and ISEcp1 on bla(CTX-M) expression. J Med Microbiol 2011, 60:1787-1792.

24. Cullik A, Pfeifer $Y$, Prager R, von BH, Witte W: A novel IS26 structure surrounds blaCTX-M genes in different plasmids from German clinical Escherichia coli isolates. J Med Microbiol 2010, 59:580-587.

25. Smet A, Van NF, Vandekerckhove $\Pi$, Martel A, Deforce D, Butaye $P$, Haesebrouck F: Complete nucleotide sequence of CTX-M-15-plasmids from clinical Escherichia coli isolates: insertional events of transposons and insertion sequences. PLOS One 2010, 5:e11202.

26. Tavakoli N, Comanducci A, Dodd HM, Lett MC, Albiger B, Bennett P: IS1294, a DNA element that transposes by RC transposition. Plasmid 2000, 44:66-84.

27. Toleman MA, Bennett PM, Walsh TR: ISCR elements: novel gene-capturing systems of the 21st century? Microbiol Mol Biol Rev 2006, 70(2):296-316.

28. Bado I, Cordeiro NF, Robino L, Garcia-Fulqueiras V, Seija V, Bazet C, Gutkind $G$, Ayala JA, Vignoli R: Detection of class 1 and 2 integrons, extendedspectrum beta-lactamases and qnr alleles in enterobacterial isolates from the digestive tract of Intensive Care Unit inpatients. Int J Antimicrob Agents 2010, 36:453-458.

29. Xia R, Guo X, Zhang Y, Xu H: qnrVC-like gene located in a novel complex class 1 integron harboring the ISCR1 element in an Aeromonas punctata strain from an aquatic environment in Shandong Province, China. Antimicrob Agents Chemother 2010, 54:3471-3474.

30. Bonnet R: Growing group of extended-spectrum beta-lactamases: the CTX-M enzymes. Antimicrob Agents Chemother 2004, 48:1-14.

31. Poirel L, Lartigue MF, Decousser JW, Nordmann P: ISEcp1B-mediated transposition of blaCTX-M in Escherichia coli. Antimicrob Agents Chemother 2005, 49(1):447-450

32. Zucker JR, Lackritz EM, Ruebush TK, Hightower AW, Adungosi JE, Were JB, Metchock B, Patrick E, Campbell CC: Childhood mortality during and after hospitalization in western Kenya: effect of malaria treatment regimens. Am J Trop Med Hyg 1996, 55:655-660.

33. Clinical and Laboratory Standards Institute: Performance standards for antimicrobial susceptibility testing. Sixteenth informational supplement M100S16. Wayne, PA: Clinical and Laboratory Standards Institute; 2006.

34. Shi L, Fujihara K, Sato T, Ito H, Garg P, Chakrabarty R, Ramamurthy T, Nair GB, Takeda Y, Yamasaki S: Distribution and characterization of integrons in various serogroups of Vibrio cholerae strains isolated from diarrhoeal patients between 1992 and 2000 in Kolkata, India. J Med Microbiol 2006, 55:575-583

35. Dalsgaard A, Forslund A, Serichantalergs O, Sandvang D: Distribution and content of class 1 integrons in different Vibrio cholerae O-serotype strains isolated in Thailand. Antimicrob Agents Chemother 2000, 44:1315-1321

36. White DG, Zhao S, Simjee S, Wagner DD, McDermott PF: Antimicrobial resistance of foodborne pathogens. Microbes Infect 2002, 4:405-412.
37. Saenz Y, Vinue L, Ruiz E, Somalo S, Martinez S, Rojo-Bezares B, Zarazaga M, Torres C: Class 1 integrons lacking qacEDelta1 and sul1 genes in Escherichia coli isolates of food, animal and human origins. Vet Microbiol 2010, 144:493-497.

38. Yu HS, Lee JC, Kang HY, Jeong YS, Lee EY, Choi CH, Tae SH, Lee YC, Seol SY, Cho DT: Prevalence of dfr genes associated with integrons and dissemination of dfrA17 among urinary isolates of Escherichia coli in Korea. J Antimicrob Chemother 2004, 53:445-450.

39. Thompson JD, Higgins DG, Gibson TJ: CLUSTAL W: improving the sensitivity of progressive multiple sequence alignment through sequence weighting, position-specific gap penalties and weight matrix choice. Nucleic Acids Res 1994, 22:4673-4680.

40. Pearson AJ, Bruce KD, Osborn AM, Ritchie DA, Strike P: Distribution of class II transposase and resolvase genes in soil bacteria and their association with mer genes. Appl Environ Microbiol 1996, 62:2961-2965.

41. Park CH, Robicsek A, Jacoby GA, Sahm D, Hooper DC: Prevalence in the United States of aac(6')-lb-cr encoding a ciprofloxacin-modifying enzyme. Antimicrob Agents Chemother 2006, 50(11):3953-3955.

42. Wu JJ, Ko WC, Wu HM, Yan JJ: Prevalence of Qnr determinants among bloodstream isolates of Escherichia coli and Klebsiella pneumoniae in a Taiwanese hospital, 1999-2005. J Antimicrob Chemother 2008, 61(6):1234-1239.

43. Arlet $G$, Rouveau M, Philippon A: Substitution of alanine for aspartate at position 179 in the SHV-6 extended-spectrum beta-lactamase. FEMS Microbiol Lett 1997, 152(1):163-167.

44. Arlet G, Brami G, Decre D, Flippo A, Gaillot O, Lagrange PH, Philippon A: Molecular characterisation by PCR-restriction fragment length polymorphism of TEM beta-lactamases. FEMS Microbiol Lett 1995, 134:203-208.

45. Lartigue MF, Poirel L, Nordmann P: Diversity of genetic environment of bla(CTX-M) genes. FEMS Microbiol Lett 2004, 234(2):201-207.

46. Winokur PL, Brueggemann A, DeSalvo DL, Hoffmann L, Apley MD, Uhlenhopp EK, Pfaller MA, Doern GV: Animal and human multidrugresistant, cephalosporin-resistant salmonella isolates expressing a plasmid-mediated CMY-2 AmpC beta-lactamase. Antimicrob Agents Chemother 2000, 44:2777-2783.

47. Olesen I, Hasman H, Aarestrup FM: Prevalence of beta-lactamases among ampicillin-resistant Escherichia coli and Salmonella isolated from food animals in Denmark. Microb Drug Resist 2004, 10(4):334-340.

48. Hasman H, Mevius D, Veldman K, Olesen I, Aarestrup FM: beta-Lactamases among extended-spectrum beta-lactamase (ESBL)-resistant Salmonella from poultry, poultry products and human patients in The Netherlands. J Antimicrob Chemother 2005, 56:115-121.

49. Jeong JY, Yoon HJ, Kim ES, Lee Y, Choi SH, Kim NJ, Woo JH, Kim YS: Detection of qnr in clinical isolates of Escherichia coli from Korea. Antimicrob Agents Chemother 2005, 49(6):2522-2524.

50. Carattoli A, Bertini A, Villa L, Falbo V, Hopkins KL, Threlfall EJ: Identification of plasmids by PCR-based replicon typing. J Microbiol Methods 2005, 63(3):219-228

\section{doi:10.1186/1471-2180-13-109}

Cite this article as: Kiiru et al.: Analysis for prevalence and physical linkages amongst integrons, ISECp1, ISCR1, Tn21 and Tn7 encountered in Escherichia coli strains from hospitalized and non-hospitalized patients in Kenya during a 19-year period (1992-2011). BMC Microbiology 2013 13:109.

\section{Submit your next manuscript to BioMed Central and take full advantage of:}

- Convenient online submission

- Thorough peer review

- No space constraints or color figure charges

- Immediate publication on acceptance

- Inclusion in PubMed, CAS, Scopus and Google Scholar

- Research which is freely available for redistribution 